\title{
A Comparison between Horizontal and Vertical Drainage Systems (Include Pipe Drainage, Open Ditch Drainage, and Pumped Wells) in Anisotropic Soils
}

\author{
Mohammad Valipour \\ Department of Irrigation and Drainage Engineering, College of Abureyhan, University of Tehran, Pakdasht,
}

\begin{abstract}
Selecting a proper drainage system always has been discussed in agricultural or other fields. In anisotropic soils, this problem is more sensitive for experts. In this study, a comparison has been done between horizontal and vertical drainage in anisotropic soils. For this purpose, using EnDrainWin and WellDrain softwares drain spacing and well spacing, respectively, determined. The results showed that in the same situation, horizontal drainage systems due to the higher spacings between drains (reducing number of drainage and thus reducing the cost) were better than vertical drainage systems. However, vertical drainage systems due to the lower changes in well spacing in different anisotropic soils were suitable for conditions that soil hydraulic conductivity was likely to change.
\end{abstract}

Keywords: Drain discharge, subsurface drainage systems design, watertable control

\section{INTRODUCTION}

The design of horizontal and vertical drainage in terms layout, depth and spacing of the drains is often done using subsurface drainage equations with parameters like drain depth, depth of the watertable, soil depth, hydraulic conductivity of the soil and drain discharge. The design of horizontal and vertical drainage systems has been aimed at many researches, which some of them will be described in the following.

Geng et al. (2012) presented analytical solutions for a single vertical drain with vacuum and timedependents preloading in membrane and membraneless systems. The analytical solutions improved the accuracy of predicting the dissipation of pore water pressure and the associated settlement. Howell et al. (2012) presented centrifuge modeling of prefabricated vertical drains for liquefaction remediation. Ghandeharioon et al. (2010) analyzed soil disturbance associated with mandrel-driven prefabricated vertical drains using an elliptical cavity expansion theory. Basu and Prezzi (2010) designed charts for vertical drains considering soil disturbance. The designed charts could also be used for conditions in which overlapping of disturbed zones occurs. Prasad et al. (2010) estimated unsaturated hydraulic parameters from infiltration and internal drainage experiments. Marinucci et al. (2010) evaluated the effectiveness of prefabricated vertical drains using full-scale in situ staged dynamic testing. Singh (2010) survived generalized analytical solutions for groundwater head in inclined aquifers in the presence of subsurface drains. Oosterbaan (2010) survived role of water harvesting and agricultural land development in spate irrigation in the NWFR of Pakistan. Coles (1968) investigated some notes on drainage design procedure. He showed that various formulas could be solved directly, but graphs have been included to simplify the solution of the different equations. Oosterbaan (1991) studied application of agricultural land drainage. Oosterbaan (1991) in other research discussed about effectiveness and social/environmental impacts of irrigation projects. Samani et al. (2004) studied flow to horizontal and slanted drains in anisotropic unconfined aquifers. Youngs (1986) discussed about water-table heights in drained anisotropic homogeneous soils. Barua and Tiwari (1995) presented theories of seepage into auger holes in homogeneous anisotropic soil. Singh et al. (1996) researched unsteady state drainage in a vertically heterogeneous soil. Endres et al. (2007) compared analytical model predictions and field measurements for pumping-induced vadose zone drainage and storage in an unconfined aquifer. The delayed drainage models predicted a relatively rapid dissipation of the undrained storage while the observed undrained storage exhibited little, if any, decay throughout the entire pumping test. Their results indicated that the water table boundary conditions used in these analytical models did not adequately replicate the mechanisms controlling the vadose zone behavior during a pumping test. Luan and Leng (2008) compared monotonic shear behaviors of granular soils under different drainage conditions. Ali (2011) studied drainage of agricultural lands as a comprehensive research. O'Kelly (2006) compared anisotropy of some soft soils. Gallichand (1994) presented numerical simulations of steady-state subsurface drainage with vertically decreasing hydraulic conductivity. The results presented could be used to estimate the error on watertable depth resulting from ignoring the vertical variations of hydraulic conductivity. Hunt (2005) discussed about flow to vertical and nonvertical wells in leaky aquifers. Choudhry et al. (1995) showed Physical and hydraulic properties of synthetic envelopes for subsurface drainage in Pakistan. Hanson and Ayars (2002) presented strategies for reducing subsurface drainage in irrigated 
agriculture through improved irrigation. Kannan (2008) Studied drawdown-drain discharge relationship and its application in design of Ccost effective subsurface drainage system in Mugogo Swamp, Busogo, Rwanda. Osiensky et al. (2000) evaluated drawdown curves derived from multiple well aquifer tests in heterogeneous environments. Moustafa (1998) survived time-dependent drainage from root zone and drainage coefficient under different irrigation management levels for subsurface drainage design in Egypt. O'Neill et al. (1989) presented agricultural subsurface drainage from potato fields in northwestern New Brunswick, Canada. Wahba and Christen (2006) modeled subsurface drainage for salt load management in southeastern Australia. Hornbuckle et al. (2005) managed controlled water table management as a strategy for reducing salt loads from subsurface drainage under perennial agriculture in semi-arid Australia. Results from the experiment showed that controlled drainage significantly reduced drainage volumes and salt loads compared to unmanaged systems. However, there were marked increases in soil salinity which will need to be carefully monitored and managed. Christen et al. (2001) designed subsurface drainage in irrigated areas of Australia, successfully. Castanheira and Santos (2009) presented a simple numerical analyses software for predicting water table height in subsurface drainage. The results obtained with the model agree well with Khirkam's and Hooghoudt analytical solution for the distribution of total head in ideal drains and for the total head calculations midway between drains. Burdon (1986) investigated hydrogeological aspects of agricultural drainage in Ireland, successfully. Ahmadi (1995) using a field approach estimated drainage coefficients in humid area. Brandyk et al. (1992) using a simple flow resistance model managed drainage/sub-irrigation systems. Wesseling (1964) compared the steady state drain spacing formulas of Hooghoudt and Kirkham in connection with design practice. Molen and Wesseling (1991) presented a solution in closed form and a series solution to replace the tables for the thickness of the equivalent layer in Hooghoudt's drain spacing formula. Wesseling (1964) studied The effect of using continually submerged drains on drain spacing. Singh et al. (1992) survived modified steady state drainage equations for transient conditions in subsurface drainage. Lovell and Youngs (1984) compared steady-state land-drainage equations. Of the drainage equations Houghoudt's equivalent depth equation, when used with the optimum drain radius given by the hodograph analysis for infinite soil depth, was the only one that gives results contained mainly within the known bounds that result from a consideration of the combination of equations. Youngs (1985) presented a simple drainage equation for predicting water-table drawdowns. This simple equation was useful in the analysis of falling water tables in drained lands. Cooke et al. (2001) studied drainage equations for random and irregular tile drainage systems. The results predicted by the derived solution were found to be in close agreement with those obtained from the numerical simulations. Therefore, it was concluded that the proposed model holds well for situations of practical import and could be used in future work with large-scale hydrologic models. Singh et al. (1999) survived subsurface drainage of a three layered soil with slowly permeable top layer. The study showed that the watertable head gets influenced by the location of interface between the soil layers. French and O'Callaghan (1966) described a field-test of drain spacing equations for agricultural land. Wiskow and Ploeg (2003) calculated drain spacing for optimal rainstorm flood control. Hirekhan et al. (2007) showed application of WaSim to assess performance of a subsurface drainage system under semi-arid monsoon climate. It appeared that WaSim was a simple tool to evaluate the hydraulic performance of the subsurface drainage systems or to design a subsurface drainage system for semi-arid monsoon climates. Prasher et al. (1994) designed water table management systems in humid areas as economical. Nwa and Twocock (1969) discussed about drainage design theory and practice. Skagges et al. (2006) studied drainage design coefficients for eastern United States. Singh and O'Callaghan (1978) investigated non-steady drainage in a layered soil. Youngs (1986) determined the variation of hydraulic conductivity with depth in drained lands and the design of drainage installations. Gureghian and Youngs (1975) using finiteelement method calculated steady-state water-table heights in drained soils. Youngs (1991) in other research said a note on the power-law land-drainage equation for deep soils.

In all previous researches, design of horizontal and vertical drainage systems has been done as separately and these two systems have not been compared particularly in anisotropic soils. In this article, compared horizontal and vertical drainage systems (include pipe drainage, open ditch drainage, and pumped wells) in anisotropic soils.

\section{MATERIALS AND METHODS}

In this study, used from two EnDrainWin and WellDrain softwares for horizontal and vertical design, respectively. The drain spacing calculations in this softwares are based on the Darcy and waterbalance (water balance, budget) or mass conservation equations. In addition obtained results for drain spacing checked with $\mathrm{L}$ Calc program. In this study, presented three different soil layers with different hydraulic conductivity and permeability: one layer above and two below drain level. The last two layers had different horizontal and vertical hydraulic conductivity or permeability (anisotropy). Figures 1 and 2 shows horizontal and vertical drainage graphs, respectively. 


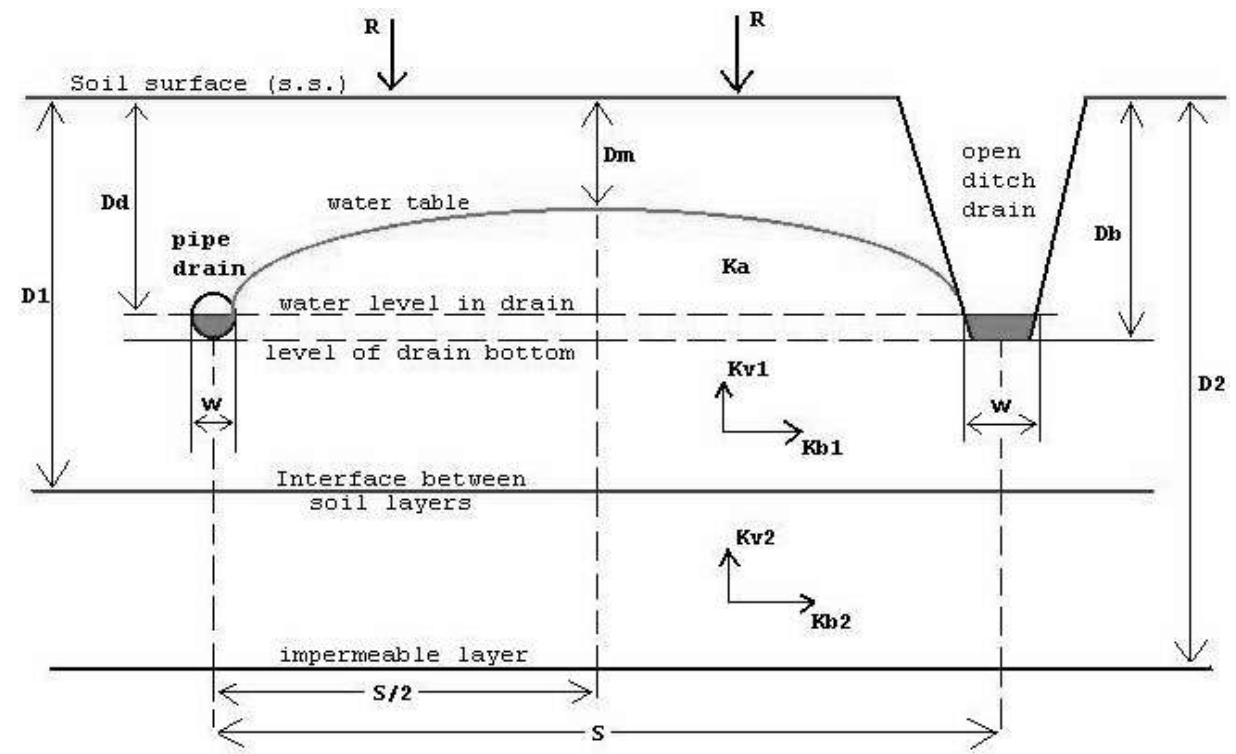

Figure 1. Horizontal drainage graph

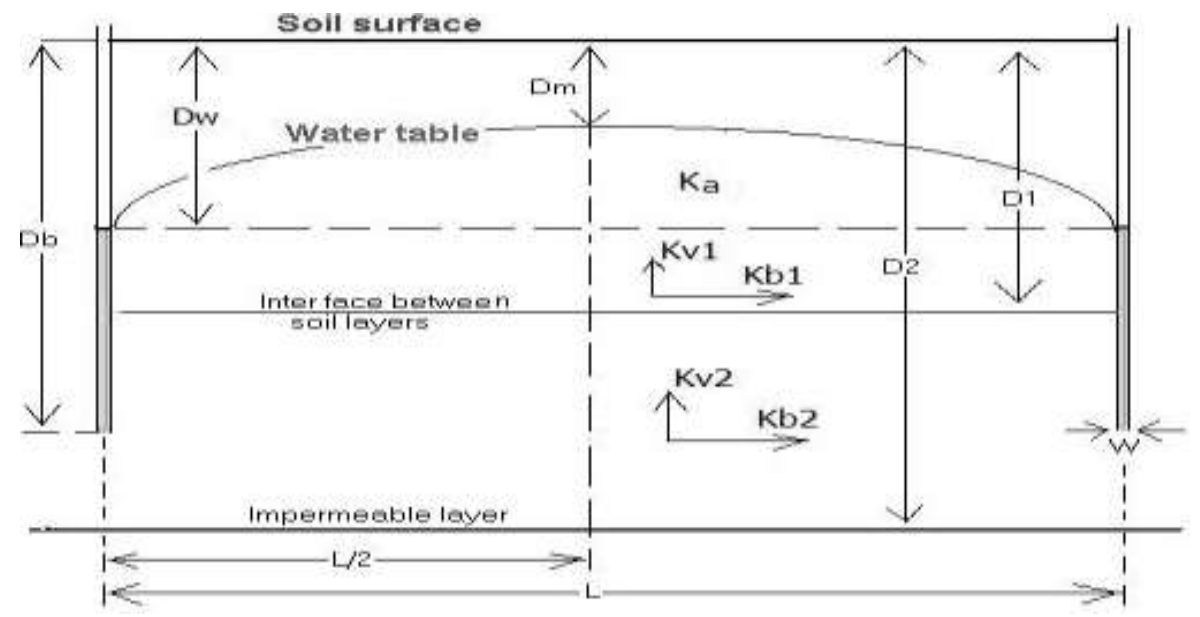

Figure 2. Vertical drainage graph

III. RESULTS AND DISCUSSION

Table 1 shows obtained results for drain and well spacing for different hydraulic conductivity.

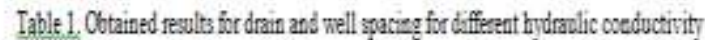

\begin{tabular}{|c|c|c|c|c|c|c|c|c|c|c|c|c|c|c|c|}
\hline $\begin{array}{c}R \\
\text { (nidar) }\end{array}$ & $\begin{array}{l}\text { Dn } \\
\text { (in) }\end{array}$ & $\begin{array}{l}D b \\
\text { (I) }\end{array}$ & $\begin{array}{l}\mathbb{R} \\
\text { (In) }\end{array}$ & $\begin{array}{l}\text { Dat } \\
\text { (In) }\end{array}$ & $\begin{array}{l}\text { D1 } \\
\text { (In) }\end{array}$ & $\begin{array}{l}\text { D2 } \\
\text { (II) }\end{array}$ & 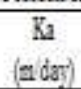 & 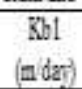 & 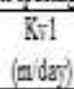 & 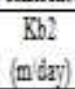 & 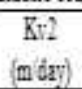 & $\begin{array}{l}\text { Drain spocing } \\
\text { (m) }\end{array}$ & $\begin{array}{l}\Delta 33 \\
(9)\end{array}$ & $\begin{array}{l}\text { Tetll spacing } \\
\text { (m) }\end{array}$ & $\begin{array}{l}\Delta s 3 \\
(9)\end{array}$ \\
\hline 00011 & 20 & 40 & 0.4 & 10 & 29 & 50 & 20 & 13 & 15 & 09 & 10 & 1720.6 & 0.0 & 68.10 & 00 \\
\hline 0.0011 & 20 & 40 & 0.4 & 10 & 2000 & 21.0 & 20 & 13 & 15 & 09 & 10 & 402.48 & 1339 & 91.78 & 34.8 \\
\hline 0.0011 & 20 & 40 & 0.4 & 10 & 21 & 21.0 & 20 & 13 & 15 & 09 & 10 & 336.44 & 955 & 79.49 & 16.7 \\
\hline 0.0011 & 20 & 40 & 0.4 & 10 & 29 & 50 & 10.0 & 13 & 15 & 09 & 10 & 24234 & 40.8 & 93.67 & 375 \\
\hline 00011 & 20 & 40 & 0.4 & 10 & 29 & 50 & 0.1 & 13 & 15 & 09 & 10 & 150.59 & 125 & 602 & 11.6 \\
\hline 00011 & 20 & 4. & 0.4 & 10 & 29 & 50 & 20 & 10.0 & 0.1 & 100 & 01 & 47254 & 1746 & 16139 & 1370 \\
\hline 00011 & 20 & 40 & 0.4 & 10 & 29 & 50 & 20 & 0.1 & 100 & 01 & 100 & 12689 & 263 & 52.75 & 225 \\
\hline 0.0011 & 20 & 4. & 0.4 & 10 & 2000 & 21.0 & 0.1 & 0.1 & 0.1 & 100 & 100 & 140.78 & 182 & $75: 30$ & 1120 \\
\hline 00011 & 20 & 40 & 0.4 & 10 & 29 & 50 & 0.1 & 10.0 & 10.0 & 100 & 100 & 57272 & 2329 & 169.19 & 148.4 \\
\hline 0,0011 & 20 & 40 & 0.4 & 10 & 100 & 210 & 0.1 & 05 & 0.7 & 10 & 15 & 34.43 & 1002 & 55.71 & 18.2 \\
\hline
\end{tabular}


According to the Table 1 for change in hydraulic conductivity, drain and well spacing also changed. The biggest changes into the initial conditions $(\Delta \mathrm{s} / \mathrm{s}=0)$ related to the condition that amount of hydraulic conductivity above of drain depth (Ka) was very low ( 0.1 meter per day) and below of drain depth $(\mathrm{Kb})$ was very high (10 meter per day). In this condition, amounts of drain and well spacing changes to initial spacings were $572.72 \%$ and $169.19 \%$, respectively. In Table 1 amounts of drain spacings are more than well spacings for each condition thus in the same situation, horizontal drainage systems due to the higher spacings between drains (reducing number of drainage and thus reducing the cost) were better than vertical drainage systems. However, vertical drainage systems due to the lower changes in well spacing in different anisotropic soils were suitable for conditions that soil hydraulic conductivity was likely to change. Therefore, in conditions that soil hydraulic conductivity is unstable and it may be essential change over time, use of vertical drainage will reduce risk of failure, efficiency decreasing, and drains spacings changing in drainage system. Figures 3 and 4 shows mode of horizontal and vertical drains action, respectively.

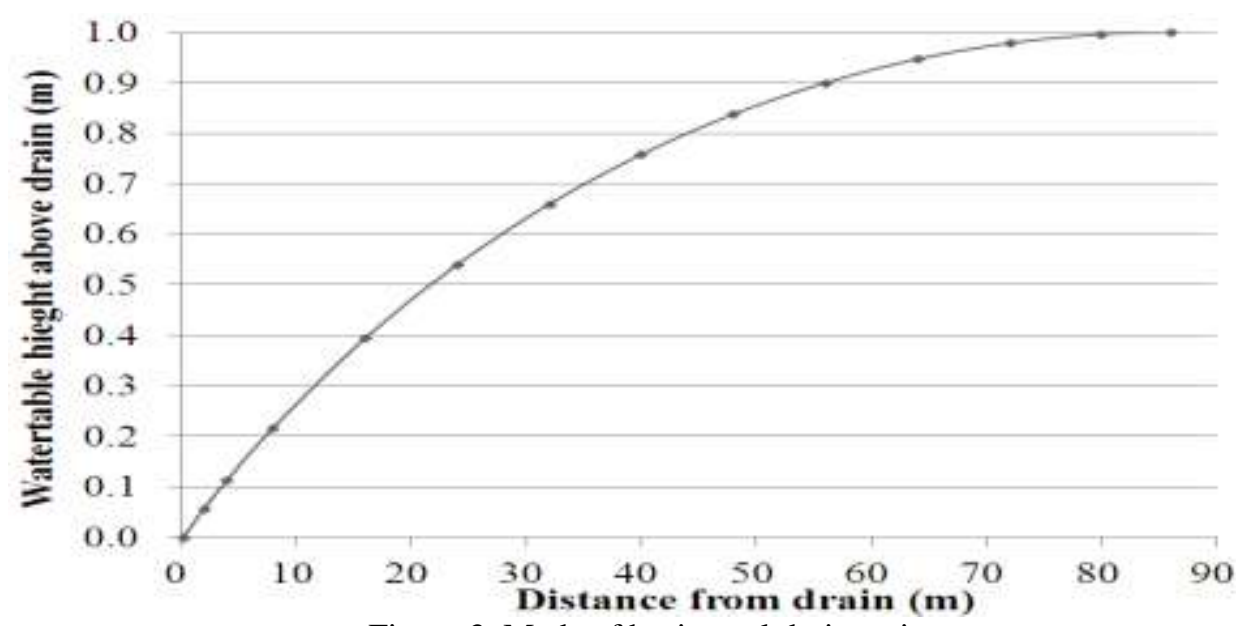

Figure 3. Mode of horizontal drain action

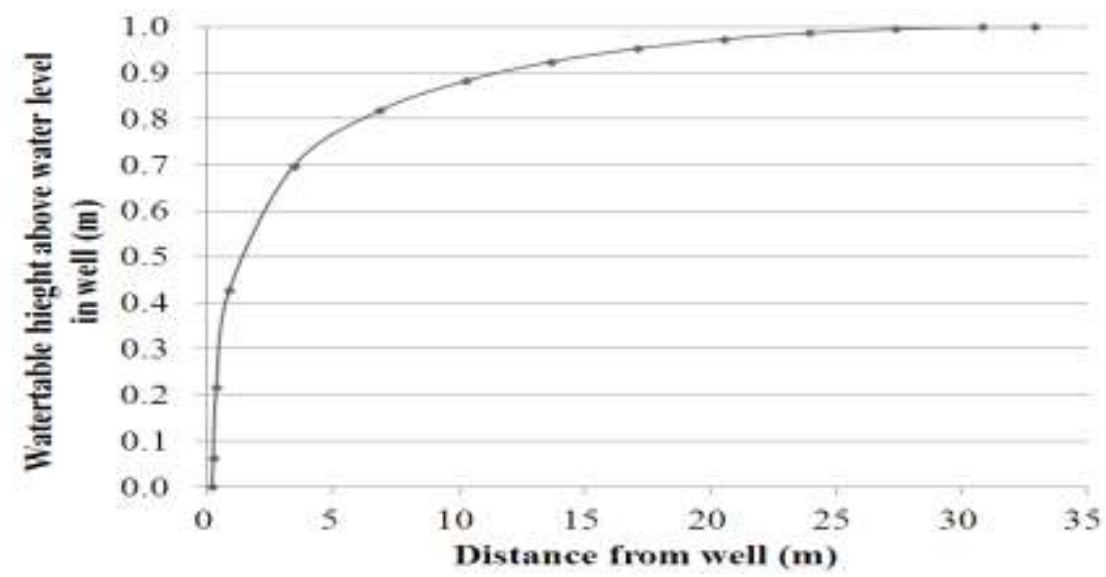

Figure 4. Mode of vertical drain action

In Figure 3, 90\% of watertable loss has been occurred in 5 meters distance from drain but in Figure 4, in 5 meters distance from well only lower than $30 \%$ of watertable loss has been occurred. In vertical drainage due to the most amount of watertable loss has been occurred in the near of well, changes of hydraulic conductivity it was less effective on well spacing into the horizontal drainage.

\section{CONCLUSION}

In this study, a comparison has been done between horizontal and vertical drainage in anisotropic soils. For this purpose, using EnDrainWin and WellDrain softwares drain spacing and well spacing, respectively, determined. The results showed that in the same situation, horizontal drainage systems due to the higher spacings between drains (reducing number of drainage and thus reducing the cost) were better than vertical drainage systems. However, vertical drainage systems due to the lower changes in well spacing in different anisotropic soils were suitable for conditions that soil hydraulic conductivity was likely to change. 


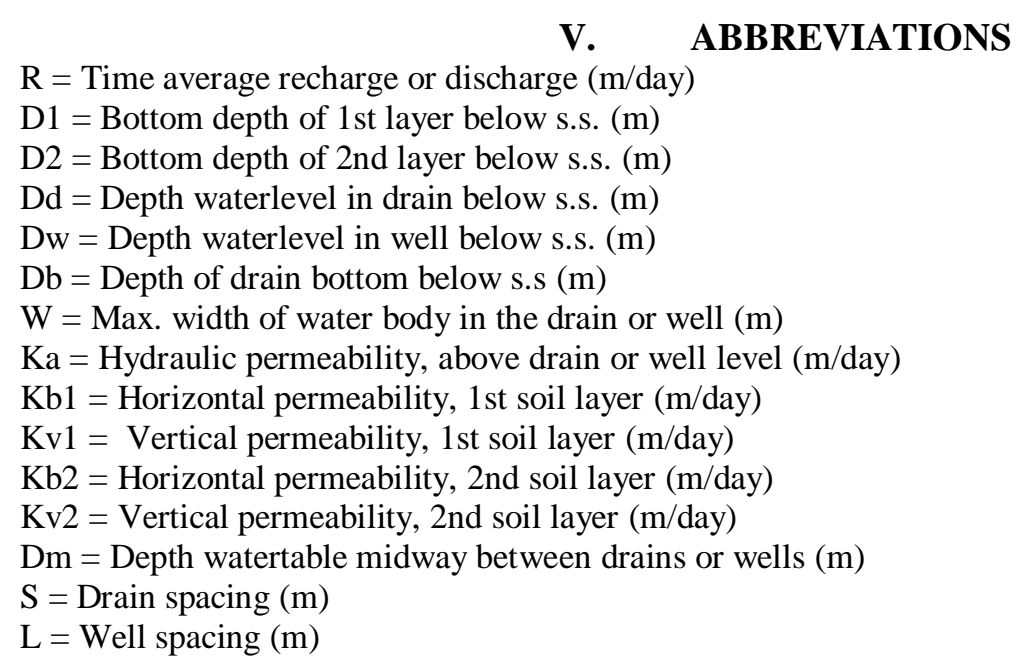

\section{REFERENCES}

[1] Ahmadi M.Z. 1995. A field approach to estimation of humid area drainage coefficients, Agricultural Water Management, 29 (1), pp. 101-109. DOI: http://dx.doi.org/10.1016/0378-3774(95)01186-2

[2] Ali M.H. 2011. Drainage of Agricultural Lands, Practices of Irrigation \& On-farm Water Management: Volume 2, pp. 327-378. DOI: 10.1007/978-1-4419-7637-6_9

[3] Barua G. and K.N. Tiwari, 1995. Theories of seepage into auger holes in homogeneous anisotropic soil, Journal of Hydrology, 167 (1-4), pp. 1-22. DOI: http://dx.doi.org/10.1016/0022-1694(94)02629-P

[4] Basu D. and M. Prezzi 2010. Design Charts for Vertical Drains Considering Soil Disturbance, Geotechnical Modeling, pp. $420-429$. DOI: http://dx.doi.org/10.1061/41095(365)39

[5] Brandyk T., P.B. Leeds-Harrison and K. Skapski 1992. A simple flow resistance model for the management of drainage/subirrigation systems, Agricultural Water Management, 21 (1-2), pp. 67-77. DOI: http://dx.doi.org/10.1016/0378-3774(92)90083-9

[6] Burdon D.J. 1986. Hydrogeological aspects of agricultural drainage in Ireland, Environmental Geology and Water Sciences, 9 (1), pp. 41-65 DOI: 10.1007/BF02439885

[7] Castanheira P.J. and F.L. Santos 2009. A simple numerical analyses software for predicting water table height in subsurface drainage, Irrigation and Drainage Systems, 23 (4), pp. 153-162. DOI: 10.1007/s10795-009-9079-5

[8] Choudhry M.R., A. Khaliq, W.F. Vlotman, H.U. Rehman 1995. Physical and hydraulic properties of synthetic envelopes for subsurface drainage in Pakistan, Irrigation and Drainage Systems, 9 (1), pp. 73-84. DOI: 10.1007/BF00881589

[9] Coles E.D. 1968. SOME NOTES ON DRAINAGE DESIGN PROCEDURE. Proceedings of The South African Sugar Technologists' Association, pp. 189-199.

[10] Cooke R.A., S. Badiger and A.M Garcia 2001. Drainage equations for random and irregular tile drainage systems, Agricultural Water Management, 48 (3), pp. 207-224. DOI: http://dx.doi.org/10.1016/S0378-3774(00)00136-0

[11] Christen E.W., J.E. Ayars and J.W. Hornbuckle 2001. Subsurface drainage design and management in irrigated areas of Australia, Irrigation Science, 21 (1). pp. 35-43. DOI: 10.1007/s002710100048

[12] Endres A.L., J.P. Jones and E.A. Bertrand 2006. Pumping-induced vadose zone drainage and storage in an unconfined aquifer: A comparison of analytical model predictions and field measurements, Journal of Hydrology, 335 (1-2), pp. 207-218. DOI: http://dx.doi.org/10.1016/j.jhydrol.2006.07.018

[13] French B.E. and J.R. O'Callaghan 1966. A field test of drain spacing equations for agricultural land, Journal of Agricultural Engineering Research, 11(4), pp. 282-295. DOI: http://dx.doi.org/10.1016/S0021-8634(66)80036-7

[14] Gallichand J. 1994. Numerical simulations of steady-state subsurface drainage with vertically decreasing hydraulic conductivity, Irrigation and Drainage Systems, 8 (1), pp. 1-12.

[15] Geng X., B. Indraratna and C. Rujikiatkamjorn 2012. Analytical Solutions for a Single Vertical Drain with Vacuum and TimeDependent Surcharge Preloading in Membrane and Membraneless Systems, International Journal of Geomechanics, 11 (1), pp. 2742. DOI: http://dx.doi.org/10.1061/(ASCE)GM.1943-5622.0000106

[16] Ghandeharioon A., B. Indraratna and C. Rujikiatkamjorn 2010. Analysis of Soil Disturbance Associated with Mandrel-Driven Prefabricated Vertical Drains Using an Elliptical Cavity Expansion Theory, International Journal of Geomechanics, 10 (2), pp. 5364. DOI: http://dx.doi.org/10.1061/(ASCE)GM.1943-5622.0000027

[17] Gureghian A.B. and E.G. Youngs 1975. The calculation of steady-state water-table heights in drained soils by means of the finiteelement method, Journal of Hydrology, 27 (1-2), pp. 15-32. DOI: http://dx.doi.org/10.1016/0022-1694(75)90096-7

[18] Hanson B.R. and J.E. Ayars 2002. Strategies for reducing subsurface drainage in irrigated agriculture through improved irrigation, Irrigation and Drainage Systems, 16 (4), pp. 261-277. DOI: 10.1023/A:1024861112978

[19] Hirekhan M., S.K. Gupta and K.L. Mishra 2007. Application of WaSim to assess performance of a subsurface drainage system under semi-arid monsoon climate, Agricultural Water Management, 88 (1-3), pp. 224-234. DOI: http://dx.doi.org/10.1016/j.agwat.2006.12.001

[20] Hornbuckle J.W., E.W. Christen, J.E. Ayars and R.D. Faulkner 2005. Controlled water table management as a strategy for reducing salt loads from subsurface drainage under perennial agriculture in semi-arid Australia, Irrigation and Drainage Systems, 19 (2), pp. 145-159. DOI: 10.1007/s10795-005-4420-0

[21] Howell R., E.M. Rathje, R. Kamai and R. Boulanger 2012. Centrifuge Modeling of Prefabricated Vertical Drains for Liquefaction Remediation, Journal of Geotechnical and Geoenvironmental Engineering, 137 (3), pp. 262-271. DOI: http://dx.doi.org/10.1061/(ASCE)GT.1943-5606.0000604

[22] Hunt B. 2005. Flow to Vertical and Nonvertical Wells in Leaky Aquifers, Journal of Hydrologic Engineering, 10 (6), pp. $477-484$. DOI: http://dx.doi.org/10.1061/(ASCE)1084-0699(2005)10:6(477) 
[23] Kannan N. 2008. Study of Drawdown-Drain Discharge Relationship and its Application in Design of Cost Effective Subsurface Drainage System in Mugogo Swamp, Busogo, Rwanda, Water Resources Management, 22 (8), pp. 1113-1125. DOI: 10.1007/s11269-007-9215-7

[24] Lovell C.J. and E.G. Youngs 1984. A comparison of steady-state land-drainage equations, Agricultural Water Management, 9 (1), pp. 1-21. DOI: http://dx.doi.org/10.1016/0378-3774(84)90015-5

[25] Luan M. and Y. Leng 2008. A Comparative Study on Monotonic Shear Behaviors of Granular Soils Under Different Drainage Conditions, Geotechnical Engineering for Disaster Mitigation and Rehabilitation, pp. 1068-1078. DOI: 10.1007/978-3-540-79846$0 \_141$

[26] Marinucci A., E.M. Rathje, J.S. Ellington, B.R. Cox, F.Y. Menq and K.H. Stokoe 2010. Evaluation of the Effectiveness of Prefabricated Vertical Drains Using Full-Scale In Situ Staged Dynamic Testing, Art of Foundation Engineering Practice, pp. 380394. DOI: http://dx.doi.org/10.1061/41093(372)17

[27] Molen W.H.V.D. and J. Wesseling 1991. A solution in closed form and a series solution to replace the tables for the thickness of the equivalent layer in Hooghoudt's drain spacing formula, Agricultural Water Management, 19 (1), pp. 1-16. DOI: http://dx.doi.org/10.1016/0378-3774(91)90058-Q

[28] Moustafa M.M. 1998. Time-dependent drainage from root zone and drainage coefficient under different irrigation management levels for subsurface drainage design in Egypt, Irrigation and Drainage Systems, 12 (2), pp. 141-159. DOI: 10.1023/A:1006055704143

[29] Nwa E.U. and J.G. Twocock 1969. Drainage design theory and practice, Journal of Hydrology, 9 (3), pp. 259-276. DOI: http://dx.doi.org/10.1016/0022-1694(69)90021-3

[30] O'Kelly B.C. 2006. Compression and consolidation anisotropy of some soft soils, Geotechnical \& Geological Engineering, 24 (6), pp. 1715-1728. DOI: 10.1007/s10706-005-5760-0

[31] O'Neill H.J., T.L. Pollock, H.S. Bailey, P. Milburn, C. Gartley and J.E. Richards 1989. Dinoseb presence in agricultural subsurface drainage from potato fields in northwestern New Brunswick, Canada, Bulletin of Environmental Contamination and Toxicology, 43 (6), pp. 935-940. DOI: 10.1007/BF01702068

[32] Oosterbaan R.J. 1988. Effectiveness and Social/Environmental Impacts of Irrigation Projects: a Criticial Review., In: ILRI Annual Report 1988, p.18-34, International Institute for Land Reclamation and Improvement, Wageningen, The Netherlands. This paper was presented at the 3rd National Irrigation and Drainage Symposium, 20 to 23 September 1988, Izmir, Turkey.

[33] Oosterbaan R.J. 1991. Agricultural Land Drainage: a wider application through caution and restraint., Lecture delivered at the symposium held to mark the occasion of the 30th International Course on Land Drainage, 27 November 1991. Published in: ILRI Annual Report 1991, p.21-36, International Institute for Land Reclamation and Improvement, Wageningen, The Netherlands.

[34] Oosterbaan R.J. 2010. Spate Irrigation: Water Harvesting and Agricultural Land Development Options in the NWFR of Pakistan, Paper submitted to the International Policy Workshop "Water Management and Land Rehabilitation, NW Frontier Region, Pakistan", Islamabad, December 6 - 8, 2010

[35] Osiensky J.L., R.E. Williams, B. Williams, G. Johnson 2000. Evaluation of drawdown curves derived from multiple well aquifer tests in heterogeneous environments, Mine Water and the Environment, 19 (1), pp 30-55. DOI: 10.1007/BF02687263

[36] Prasad K.S.H., C.S.P. Ojha, P.N. Chandramouli and C.A. Madramootoo 2010. Estimation of Unsaturated Hydraulic Parameters from Infiltration and Internal Drainage Experiments, Journal of Irrigation and Drainage Engineering, 136 (11), pp. 766-773. DOI: http://dx.doi.org/10.1061/(ASCE)IR.1943-4774.0000234

[37] Prasher S.O., A. Madani, R.S. Clemente, G.Q. Geng and A. Bhardwaj 1996. Evaluation of two water table management models for Atlantic Canada, Agricultural Water Management, 32 (1), pp. 49-69. DOI: http://dx.doi.org/10.1016/S0378-3774(96)01260-7

[38] Prasher S.O., S.F. Barrington and A.M. Darbary 1994. Economical design of water table management systems in humid areas, Computers and Electronics in Agriculture, 10 (3), pp. 229-244. DOI: http://dx.doi.org/10.1016/0168-1699(94)90043-4

[39] Samani N., M. Kompani-Zare, H. Seyyedian and D.A. Barry 2004. Flow to horizontal and slanted drains in anisotropic unconfined aquifers, Developments in Water Science, 55 (1), pp. 427-440. DOI: http://dx.doi.org/10.1016/S0167-5648(04)80070-4

[40] Singh B. and J.R. O'Callaghan 1978. Non-steady drainage in a layered soil, Journal of Agricultural Engineering Research, 23 (4), pp. 417-427. DOI: http://dx.doi.org/10.1016/0021-8634(78)90056-2

[41] Singh K.M., O.P. Singh, S. Ram and H.S. Chauhan 1992. Modified steady state drainage equations for transient conditions in subsurface drainage, Agricultural Water Management, 20 (4), pp. 329-339. DOI: http://dx.doi.org/10.1016/0378-3774(92)90006-I

[42] Singh M.P., H.S. Chauhan and S. Ram 1996. Unsteady state drainage in a vertically heterogeneous soil, Agricultural Water Management, 31 (3), pp. 285-293. DOI: http://dx.doi.org/10.1016/0378-3774(96)01239-5

[43] Singh P.K., O.P. Singh, C.S. Jaiswal and H.S. Chauhan 1999. Subsurface drainage of a three layered soil with slowly permeable top layer, Agricultural Water Management, 42 (1), pp. 97-109. DOI: http://dx.doi.org/10.1016/S0378-3774(99)00027-X

[44] Singh S.K. 2010. Generalized Analytical Solutions for Groundwater Head in Inclined Aquifers in the Presence of Subsurface Drains, Journal of Irrigation and Drainage Engineering, 136 (3), pp. 194-203. DOI: http://dx.doi.org/10.1061/(ASCE)IR.19434774.0000150

[45] Skaggs R.W., M.A. Youssef and G.M. Chescheir 2006. Drainage design coefficients for eastern United States, Agricultural Water Management, 86 (1-2), pp. 40-49. DOI: http://dx.doi.org/10.1016/j.agwat.2006.06.007

[46] Wahba M.A.S. and E.W. Christen 2006. Modeling subsurface drainage for salt load management in southeastern Australia, Irrigation and Drainage Systems, 20 (2-3), pp. 267-282. DOI: 10.1007/s10795-006-9007-x

[47] Wesseling J. 1964. A comparison of the steady state drain spacing formulas of Hooghoudt and Kirkham in connection with design practice, Journal of Hydrology, 2 (1), pp. 25-32. DOI: http://dx.doi.org/10.1016/0022-1694(64)90062-9

[48] Wesseling J. 1964. The effect of using continually submerged drains on drain spacings, Journal of Hydrology, 2 (1), pp. $33-43$. DOI: http://dx.doi.org/10.1016/0022-1694(64)90063-0

[49] Wiskow E. and R.R.V.D. Ploeg 2003. Calculation of drain spacings for optimal rainstorm flood control, Journal of Hydrology, 272 (1-4), pp. 163-174. DOI: http://dx.doi.org/10.1016/S0022-1694(02)00262-7

[50] Youngs E.G. 1976. Determination of the variation of hydraulic conductivity with depth in drained lands and the design of drainage installations, Agricultural Water Management, 1 (1), pp. 57-66. DOI: http://dx.doi.org/10.1016/0378-3774(76)90007-X

[51] Youngs E.G. 1985. A simple drainage equation for predicting water-table drawdowns, Journal of Agricultural Engineering Research, 31 (4, pp. 321-328. DOI: http://dx.doi.org/10.1016/0021-8634(85)90108-8

[52] Youngs E.G. 1986. Water-table heights in drained anisotropic homogeneous soils, Agricultural Water Management, 11 (1), pp. 111. DOI: http://dx.doi.org/10.1016/0378-3774(86)90031-4

[53] Youngs E.G. 1991. A note on the power-law land-drainage equation for deep soils, Journal of Agricultural Engineering Research, 49, pp. 161-163. DOI: http://dx.doi.org/10.1016/0021-8634(91)80036-E 